\title{
EVOLUTION OF CRARY ICE RISE, ANTARCTICA
}

(Abstract)

\author{
by
}

Robert Bindschadler,

(Code 671, NASA Goddard Space Flight Center, Greenbelt, MD 20771, U.S.A.)

Bruce Koci,

(Polar Ice Coring Office, University of Nebraska, Lincoln, NB 68588-0200, U.S.A.)

Sion Shabtaie,

(Geophysical and Polar Research Center, University of Wisconsin-Madison, 1215 West Dayton Street, Madison, WI 53706-1692, U.S.A.)

and

Eric Roberts

(Department of Geology, University of Maryland, College Park, MD 20740, U.S.A.)

Crary Ice Rise plays a critical role in determining the ice flow of the south-eastern Ross Ice Shelf. Lying directly in the path of Ice Stream B, back pressure from the ice rise is transmitted hundreds of kilometers up the ice stream from the grounding line. The ice rise's influence is particularly widespread due to the presence of the "ice plain", a broad region of shallow-sloped ice at the mouth of the ice stream and loosely coupled to the underlying bed material. For this reason, the current behavior of the West Antarctic ice sheet is affected by the evolution of Crary Ice Rise.

Past analyses have resulted in conflicting interpretations of the history of this ice-shelf feature. MacAyeal and Thomas (1980) calculated that a measured profile of elevation across the ice rise made during the RIGGS project was lower than the equilibrium profile, thus inferring current growth of the ice rise. In contrast, Jezek (1984) used other RIGGS data and showed that the debris traces in the ice shelf down-stream from the ice rise were not parallel to the current flow direction. He hypothesized a mechanism to explain this difference based on a retreating grounding line (or boundary) of the ice rise. More recent data, analyzed by MacAyeal and others (1987), indicate an average thickening rate of $0.44 \mathrm{~m} / \mathrm{a}$ in the region of Crary Ice Rise. Finally, aerial photography of the ice rise taken in 1985 has revealed a discrete "ice raft" separating from the main ice rise (Bindschadler and others, 1988). Such a separation can be interpreted as part of an episodic disintegration of the ice rise.

To resolve the question of whether Crary Ice Rise is a remnant of an advanced Wisconsin-aged ice sheet when most or all of the Ross Ice Shelf was grounded and which has since experienced extensive retreat, or whether the ice rise is a recently formed feature, a technique used by Lyons and others (1972) to date the time of initial grounding for ice rises on the Ward Hunt Ice Shelf was employed. The technique compares the measured temperature versus depth profile of the ice rise to temperature profiles calculated by a numerical model. The model predicts the transient temperatures of the ice as the base of the ice cools after grounding. Initially, the basal ice is in contact with sea-water (at a known temperature of about $-2{ }^{\circ} \mathrm{C}$ at the ice/water contact); after grounding, the basal temperature condition shifts to a specified basal heat flux deep within the underlying bedrock. Our model, similar to that of MacAyeal and Thomas (1980), ignores horizontal conduction and advection but includes vertical conduction and advection, as well as non-equilibrium vertical strain and variable density.

Two holes were drilled on Crary Ice Rise in December 1987. The first, $370 \mathrm{~m}$ deep, was drilled in the vicinity of the shallowest bedrock known to exist under the ice rise from airborne radar-sounding data. A second hole, $480 \mathrm{~m}$ deep, was drilled $15 \mathrm{~km}$ south-south-west on the highest ridge of the ice rise. Temperatures were measured in each hole as soon as the thermistor cables were in place. In the shallower hole, measurements were made for $11 \frac{1}{2} \mathrm{~d}$. During this time all thermistors cooled, froze-in, and cooled further. The only exceptions were the two thermistors at the base which remained at the pressure-melting temperature throughout the $11 \frac{1}{2} \mathrm{~d}$ period. $10 \mathrm{~m}$ above the bed, freeze-in occurred after only $4 \mathrm{~d}$. The rates of cooling decreased markedly with depth, indicating warmer ice temperatures with depth. Rates of cooling near the bed were so small that it is difficult to anticipate basal temperatures much colder than the $-2^{\circ} \mathrm{C}$ temperature which corresponds to the basal temperature at the time of grounding. We have calculated that a basal heat flux of $0.165 \mathrm{~W} / \mathrm{m}^{2}$ would be required to maintain a basal temperature of $-2^{\circ} \mathrm{C}$. Because this value of heat flux is unreasonably large, we feel that the warm basal ice at this location is strong evidence that Crary Ice Rise is a recent feature: at most a few centuries old.

This result and other recently published findings are consistent with a recent increase in activity of Ice Stream B. These findings include:

(1) Current negative net mass balance of Ice Stream B (Shabtaie and others, 1988; Whillans and Bindschadler, 1988).

(2) Thickening in the region of Crary Ice Rise (MacAyeal and others, 1987).

(3) Recent age of Crary Ice Rise (this work).

(4) Deceleration of the Ice Stream B "ice plain" (Stephenson and Bindschadler, 1989).

(5) "Raft" separation from Crary Ice Rise (Bindschadler and others, 1988).

A possible evolutionary sequence which ties these results together begins with a recent increase in activity of Ice Stream B, causing a strongly negative net mass balance. The magnitude of this negative mass balance (about 43\%) does not suggest a brief period of activity (such as a surge where discharge fluxes are one to two orders of magnitude above balance) but rather a modest increase in activity which could be sustained for well over a century. The excess ice discharged by the negative net balance must have entered the Ross Ice Shelf as a wave of thickening. It was this thickening which, we believe, formed Crary Ice Rise. This thickening appears to be still under way and is responsible for the deceleration of the "ice plain". We expect this process to be accompanied by an advance of the grounding line but cannot report direct measurements. As Crary Ice Rise grows and presents an ever-increasing obstacle to the discharge of ice from Ice Stream B, it is expected that the ice stream will need to adjust to maintain 
its discharge. This can be by any number of mechanisms involving its own shape (slope, width, and thickness), as well as the shape of Crary Ice Rise. We observe that the separation of the raft has served to make the ice rise more streamlined to the discharge of Ice Stream B. This streamlining may be a direct result of the interaction between an accelerating ice stream and a forming ice rise.

\section{REFERENCES}

Bindschadler, R.A., P.L. Vornberger, S.N. Stephenson, E.P. Roberts, S. Shabtaie, and D.R. MacAyeal. 1988. Ice-shelf flow at the boundary of Crary Ice Rise, Antarctica. Ann. Glaciol., 11, 8-13.

Jezek, K.C. 1984. Recent changes in the dynamic condition of the Ross Ice Shelf, Antarctica. J. Geophys. Res., 89(B1), 409-416.

Lyons, J.B., R.H. Ragle, and A.J. Tamburi. 1972.
Growth and grounding of the Ellesmere Island ice rises J. Glaciol., 11(61), 43-52.

MacAyeal, D.R. and R.H. Thomas. 1980. Ice-shelf grounding: ice and bedrock temperature changes. $J$. Glaciol., 25(93), 397-400.

MacAyeal, D.R., R.A. Bindschadler, S. Shabtaie, S.N. Stephenson, and C.R. Bentley. 1987. Force, mass and energy budgets of the Crary Ice Rise complex, Antarctica. J. Glaciol., 33(114), 218-230.

Shabtaie, S., C.R. Bentley, R.A. Bindschadler, and D.R. MacAyeal. 1988. Mass-balance of Ice Streams A, B, and $\mathrm{C}$, West Antarctica, and possible surging behavior of Ice Stream B. Ann. Glaciol., 11, 137-149.

Stephenson, S. and R. Bindschadler. 1989. Observed velocity fluctuations on a major Antarctic ice stream. (Abstract.) Ann.. Glaciol., 12, 215-216.

Whillans, I.M. and R.A. Bindschadler. 1988. Mass balance of Ice Stream B, West Antarctica. Ann. Glaciol., 11, 187-193.

\title{
SEISMIC EVIDENCE FOR A THIN BASAL LAYER
}

\section{AT A SECOND LOCATION ON ICE STREAM B, ANTARCTICA}

\section{(Abstract)}

by

D.D. Blankenship, S.T. Rooney, R.B. Alley, and C.R. Bentley

(Geophysical and Polar Research Center, University of Wisconsin-Madison,

1215 West Dayton Street, Madison, WI 53706-1692, U.S.A.)

Seismic experiments have shown that a meters thick layer of unconsolidated sediment exists beneath Ice Stream B at a location that is several hundred kilometers up-stream from the grounding line. In previous work, we have proposed that a "coupling" line exists about $100 \mathrm{~km}$ upstream from the grounding line. Above the coupling line, we believe that the dynamic behavior of Ice Stream B is dominated by deformation within the basal sediment layers and that erosion is taking place at the bottom of this layer. Below the coupling line, we believe that sliding on a lubricating water film becomes increasingly important and that the subglacial sediments are deposited as a delta. Preliminary results from a $30 \mathrm{~km}$ seismic profile near the coupling line of Ice Stream B show a prominent horizontal reflector several meters below the base of the ice; this reflector is underlain by a sequence of reflectors, each with a down-stream dip of about $1 \%$. We believe that the horizontal and dipping reflectors represent, respectively, the topsets and foresets of the hypothesized delta.

\section{DERIVATION OF FLOW-LAW PROPERTIES FROM BORE-HOLE TILT DATA: DISCUSSION OF THE DYE 3, CAMP CENTURY, AND BYRD STATION BORE-HOLE RESULTS}

\author{
(Abstract) \\ by \\ D. Dahl-Jensen and N.S. Gundestrup \\ (Department of Glaciology, Geophysical Institute, University of Copenhagen, \\ Haraldsgade 6, DK-2200 Copenhagen N, Denmark)
}

Derivation of flow properties from bore-hole tilts is a popular way of determining flow properties of "real" glacier ice. Many interpretations have been made of the measurements from the Camp Century bore hole (Paterson, 1983; Wolff and Doake, 1986), the Byrd Station bore hole (Paterson, 1983; Doake and Wolff, 1985), and the Dye 3 bore hole (Dahl-Jensen and Gundestrup, 1987; Pimienta and Duval, 1987) where the flow-law exponent in Glen's flow law has values ranging from 1 to 3 . The great allowance for variations in the exponent is primarily due to the experimental error in the tilt measurements.

The high-quality bore-hole tilt data from the $2037 \mathrm{~m}$ deep Dye 3 bore hole are used to illustrate some of the difficulties which are connected with the use of field measurements to determine flow-law parameters. In the $250 \mathrm{~m}$ thick bottom layer of Wisconsin ice, where $80 \%$ of the deformation occurs, the deformation rates are enhanced by the varying impurity concentrations and crystal sizes. 